\title{
Effectiveness of Using the Project-Based Learning Model in Improving Creative-Thinking Ability
}

\author{
Sri Rahayu Ningsih*, Disman, Eeng Ahman, Suwatno, Ari Riswanto \\ Graduate School, Universitas Pendidikan Indonesia, Indonesia
}

Received May 30, 2019; Revised February 27, 2020; Accepted March 12, 2020

Copyright $\bigcirc 2020$ by authors, all rights reserved. Authors agree that this article remains permanently open access under the terms of the Creative Commons Attribution License 4.0 International License

\begin{abstract}
To facilitate students' learning, the task of the teacher is not only to provide subject matter but also to explain the practical benefits to students, pursued dynamically by giving students to engage actively to explore the opportunity, problems and challenges by project-based learning to gain deeper and contextual knowledge. To verify the extent to which, the Project-Based Learning (PjBL) model is carried out to examine students' contextual abilities. The purpose of this study is to investigate the effectiveness of using the project-based learning model in improving the ability to think creatively on economic subjects at high-school students in West Bandung Regency, West Java, Indonesia. The method was quasi experiments by classifying the respondents to the experimental class and the control class. The data was collected from a sample of 79 students. The results showed that there were differences in creative thinking between the use of project-based learning models in the experimental class compared with the use of expository methods in the control class. These findings demonstrated that project-based learning has the potential to provide interesting and relevant learning experiences for students. Theoretically, this finding confirms about the need for teachers to evaluate the results of student performance products during the project-based learning process. The findings practically emphasize the focus of learning with project-based learning and other meaningful tasks, by giving students the opportunity to work autonomously in constructing knowledge and for make products.
\end{abstract}

Keywords Creative-Thinking Ability, Project-Based Learning, Quasi Experiments

\section{Introduction}

Education must be able to develop students' talents and abilities to develop, and broadly must be able to provide stimuli for the development of society at large (Kozma, 2005; Fägerlind \& Saha, 2016). With the provision of education obtained at school, graduates are expected to enable themselves to develop strong abilities and enthusiasm for the achievement of qualified human development through the education process (Samir \& Lutz, 2017). The teacher plays an important role in producing quality graduates, a concept which is known with teacher educator (Le Cornu, 2015). Among key responsibilities they hold is regulating the environment and learning strategies that enable students to gain experience and understanding of information obtained from discoveries that students do (for overview, see, Savery, 2015). Hence, schools must try to bring out the creative thinking abilities of students (Bereiter \& Scardamalia, 2003). Students are expected to be able to face increasingly rapid competition. In this case, the problem is that many students just rely on temporary abilities. This means that the ability only appears when students get something from a teacher or person who is considered capable. Students can implement the results of their work from what is obtained without wanting to give a little innovation or give a little touch of creative thinking (de Souza Fleith, 2000; Grigorenko \& Sternberg, 1997).

Based on observations made, it was found that most teacher in classroom context in Indonesian case from the beginning of the study did not provide information about the objectives of the learning that must be achieved by students (see for instance, Kusumawardhani, 2017; Yanuarti \& Treagust, 2016). Students are only given an explanation of the material which then works on the questions. Students look uncomfortable in class because they are afraid to work on the questions on the board. The reality that occurs in the field is economic learning at the level of secondary education which has been characterized by learning that is more dominated by the teacher than students (teacher centered) (Aljughaiman \& Mowrer Reynolds, 2005), where students are more focused on 
memorizing formulas for all types or characteristics of subject matter, especially in economics. To facilitate students' learning, the task of the teacher is not only to provide subject matter but also to explain the benefits and philosophy of the lesson to students. Learning should not only emphasize subject matter alone, but must be pursued dynamically where students are actively given the opportunity to explore problems and challenges in the real world in order to gain deeper and contextual knowledge. In the field of education, this kind of strategy refers to project-based learning model. To verify the extent to which, the Project-Based Learning (PjBL) model is carried out in a developing country, and is able to develop students' contextual abilities, the purpose of this study is to identify the effectiveness of using the project-based learning model in improving the ability to think creative on economic subjects, high-school students in West Bandung Regency, West Java, Indonesia. Quasi experiments were chosen as the method in this study so that they were divided into two groups of respondents, namely the experimental class and the control class.

\section{Literature Review and Hypotheses}

\subsection{Creative Thinking Ability}

Data from International Association for the Evaluation of Educational Achievement (IEA) (Mullis et al., 2007) showed that student's reading literacy achievement in developing countries, including Indonesia, is lagging behind and getting lower scores than developed countries. This ability is not only related to functional literacy, but also with critical literacy related to the deepening of information and creative thinking, where students are able to analyze well and critically on various information and contextual conditions. As a result, students are less able to provide original and innovative ideas. Students tend to be more receptive to information than to provide idea that can solve the problem at hand. To find the facts and concepts themselves and realize the ideas they have that can be applied directly in everyday life. There are so many learning models that are applied only to the delivery of material. The teacher need to give students the opportunity to make a project or work where students can express or demonstrate creative thinking skills in their economic knowledge to overcome problems that exist in their daily lives (Vulpe \& Dinaofiiun, 2011). In fact, education schools in West Bandung Regency, West Java Province, Indonesia is generally considered to still not support the growth and development of students' creative thinking abilities. The use of learning mostly tends to be an activity of memorizing facts and the rest is not related to the daily lives of students. Hence, students have difficulty connecting what has been and has just learned about the environment and experience in their lives.
Ammermueller (2007) explains that immigrants from underdeveloped countries are more likely to be less standardized on international programs. Learning only delivers students to the level of understanding, but not yet at the level of applying the knowledge gained in the cases it faces. As a result, students can only work as exemplified by their teacher. Consequently, if the problems faced are different in presentation, students have difficulty in completing the tasks (Lubis \& Manurung, 2010). The constructivist approach reminds us that learning is not limited to an important theoretical idea. Constructivism provides the opportunity for students to construct their own knowledge, which means training students to think and be responsible for their thoughts (Trianto, 201). Moreover, Sugilar (2013) asserts that with the foundation of constructivism, students will be able to improve creative thinking skills.

\subsection{Project-Based Learning}

One effort to improve students' analytical skills is by using an interesting learning model, helping students to understand material concepts and helping students connect concepts that they already have with the real world. One of the appropriate learning models for this is the Project-Based Learning (PjBL) model (Mihardi et al., 2013; Chu et al., 2010). The PjBL model has the great potential to provide a more interesting and meaningful learning experience for students. This model is one of the developments of constructivist learning theory, where humans as learners must build their own knowledge in the context of their experiences. In project-based learning, students become more active in learning. The teachers evaluate the results of the students' performance products, including outcomes that are able to be displayed from the results of the project being worked on (Helle et al., 2006). Project-based learning has the potential to provide interesting and relevant learning experiences for students. The focus of learning lies in the principles and concepts of a scientific discipline, involving students in investigating problem-solving and other meaningful tasks, giving students the opportunity to work autonomously in constructing knowledge and for making products. The Project-Based Learning model requires students to actively explore real-world challenges and problems. Thus students must first analyze the problems that occur around them. This will increase the thinking power and ability of students in the classroom, such as the ability to analyze.

The Project-Based Learning (PjBL) model is learning that is based on constructivist theory (Chu et al., 2011). Participating students can improve their ability to think creatively and solve problems (Tretten \& Zachariou, 1995). The results of Tretten \& Zachariou's (1995) study showed a positive effect of The Project-Based Learning (PjBL) on low-ability students, namely by increasing the use of creative thinking skills, including synthesis, 
evaluation, predicting, and reflecting back up by $46 \%$ while high-ability students rise to $76 \%$ (Horan et al., 1996) The ability to think creatively can be developed by adopting the regional economic potential in learning. Ideal learning is learner-oriented learning (student centered), students will try to construct their own knowledge and be actively involved in finding information (Permendiknas No. 22 of 2006). One of the lessons that are expected to be able to overcome these problems is through the Project-Based Learning (PjBL) approach. The focus of this learning model lies in the concepts and core principles of a study discipline, involving students in investigating problem-solving and other meaningful tasks, giving students the opportunity to work autonomously to construct their own knowledge, and to minimize it in real products (Bell, 2010; Snyder \& Snyder, 2008; Mills \& Treagust, 2003).

\subsection{Effects of Project-Based Learning on Creative Thinking Abilities}

Some previous studies have analyzed the relationship between Project-based learning and students' creative thinking abilities with different theoretical and practical approaches and methods.Nunn et al. (2016) tested PjBL with students' critical abilities by dividing students in teams to undertake projects throughout the semester, and students' written work on the same project and linking it to students' critical abilities. In the comparative study design, Anazifa and Djukri (2017) presented an analysis between problem-based learning and project based learning, and found that there are differences in the influence of project-based learning and problem-based learning on student creativity. This study shows that PjBL affects student creativity at a $95 \%$ confidence level. However, this study did not specifically use the analysis of the effect of PjBL on student creativity. Uziak (2016) further stated that project-based learning has been widely regarded as an effective and innovative method for education, including technical education, where the PjBL allows students to practice professional engineering openly. The findings of Uziak (2016) highlight project-based learning as the best effort to meet industry needs.

By linking project-based learning and creative thinking, it has been put into practice in computer science courses on the design and implementation of learning platforms. With an experimental-control design, the study of Gunawan et al. (2017) analyzed the effect of virtual media-assisted models on student creativity, and found that increased creativity in the experimental class was higher than the control class. The study of Sari et al. (2017) with the experimental and control class design, found there were significant differences in creative thinking skills both in fluency, flexibility, novelty, and detail between the two classes. The final findings state that project-based learning can improve students' creative thinking skills. Based on this, the hypothesis proposed is that there are differences in creative thinking skills between students who were treated with project-based learning in the experimental class and those who did not receive treatment in the control class. In other words, this hypothesis assumes that project-based learning will likely be able to improve students' creative thinking skills.

\section{Research Methodology}

This research method uses experiments. Experimental research according to Taniredja and Mustafiah (2011) is a systematic and logical method to answer a question. The researchers used something as stimuli, treatments, or empirical conditions, then observes the effects or changes caused by deliberate and reasonable manipulations. The exploratory design in this study is quasi experimental, which helps researchers to see the causal relationship of various situations that exist because it is a variation of classic speculative research (Prasetyo \& Jannah, 2005). This study was divided into two groups of students, namely the empirical class group with the project-based learning model and the control group through expository learning. In accordance with the type of research design used, the design in this study is the non-equivalent pre-test-post-test control group design. There are two groups of the experimental group and the control group.

The instrument's testing in this study were student learning outcomes in the form of objective tests or multiple-choice tests to see students' creative-thinking ability learning economics. This research is on economic / accounting subjects with the subject of financial statements (worksheets). The instrument used in the study can be explained as follows: For pretest and posttest use multiple choice questions to measure the level of student understanding. There are 50 multiple choice questions used in this study. Students are also confronted with a financial statement in the form of a balance sheet as a guide for working on certain multiple choice questions. The PjBL application in this study is located here. Some examples of multiple choice questions are as follows:

1) The following are not activities at the summary stage in the accounting process, with choices (a) compiling a residual list, (b) keeping an adjusting journal, (c) compiling worksheet, (d) making a profit balance loss, (e) keeping a closing journal entries

2) The stage after posting to the ledger is (a) adjustment, (b) balance sheet preparation, (c) journal entry, (d) arrange worksheet, (e) preparation of a trial balance

3) The data source for making a trial balance is (a) initial balance sheet, (b) proof of transaction, (c) balances in the ledger, (d) journal entry, (e) transaction

Meanwhile, PjBL and creative thinking use a 
questionnaire with a Likert scale. Student questionnaire responses to the project-based learning model on the concept of financial statements (worsheet), which was conducted by responding to questions raised with a range of answers from 1 (strongly disagree) to 5 (strongly agree) according to a Likert scale. The purpose of this response questionnaire is to determine students' responses to learning by applying a project-based learning model, in which this questionnaire contains 12 questions, and students are asked to carefully consider each item in relation to subject matter using the project-based learning model.

Examples of questions are such as the Project-based Learning Model (PjBL) makes teaching and learning activities more interesting and enjoyable, the PjBL model implemented motivates me to be more active in learning, THE PBL model motivates me to further highlight creativity in implementing a project, and the PjBL student worksheet helps me design a project.

As for the creative thinking questionnaire as an indicator of the ability to think creatively, it is done by giving blank entries to be filled in accordance with responses between 1 (strongly disagree) to 5 (strongly agree). The ability to think creatively is indicated by several indicators, namely students are able to have smooth thinking, flexible thinking, original thinking, elaborative thinking, and evaluative thinking. Each indicator was measured by some items.

Smooth thinking is proxied with 5 items, namely asking lots of questions, answering with a number of answers if there are questions, working faster than other friends, doing more than other friends, and quickly seeing the mistakes and weaknesses of an object or situation.

Flexible thinking is measured by 4 items, namely giving various interpretations of a picture, story or problem, applying a concept or principle in different ways, giving consideration or discussing something always that has a different position or contrary to the majority of the group, and if given a problem, usually thinking of a variety of different ways to solve it.

Original thinking is measured by 4 items, namely thinking about problems or things that have never been thought of by others, questioning old ways and trying to think of new ways, giving new ideas in solving problems and after hearing or reading ideas, working to get new settlement.

Elaborative thinking is measured by 4 items, namely searching for a deeper meaning to the answer or problem solving by taking detailed steps, developing/enriching other people's ideas, tendency to give broad and satisfying answers, able to build interrelationships between concepts.

Evaluative thinking is measured by 4 items, namely giving consideration on the basis of one's own point of view, analyzing problems / solutions critically by always asking "why?", Having (rational) reasons that can be accounted for to reach a decision, and determining opinions and holding on to it.
The purpose of this creative thinking response questionnaire is to find out students' responses to learning by applying a project-based learning model. This questionnaire contains 12 questions, where students are asked to carefully consider each question in relation to subject matter that uses a project-based learning model. Students are asked to make choices about questions that are already available by providing a checklist $(\sqrt{ })$ in the scale column, with the answers to be given are considered to best reflect students' opinions.

Experimental respondents were examined using PjBL while control respondents were examined using conventional lectures

The instrument trial results show the results of validities' tests on 70 questions obtained by a validity number of 50 questions or around $71 \%$, which are used as instruments representing research indicators to measure students' creative-thinking skills in economic learning. Next, the calculation of the reliability of the problem is calculated using the even and odd cleavage method. Based on the reliability test, it shows that the level of reliability according to the odd method reaches 0.936, when compared with the Pearson 0.329 table it has reliable criteria with a very high category. Likewise, the even method reaches 0.967 compared to the Pearson 0.329 table which has reliable criteria with a very towering category. The research hypothesis test is based on pre-test and data values Normalized Gain (N-Gain). According to Sugiyono (2008), for independent samples (uncorrelated he has a provision, if both data are normally distributed and the variance is homogeneous, it is proceed with the $t$ test ( $\mathrm{t}$ test).

\section{Results}

The results as seen in Table 1 show the explorative thinking ability of the experimental class and the control class. First for the experimental class with 40 students. The posttest mean score $(\mathrm{m}=22.32$; $\mathrm{S} . \mathrm{D}=3.856)$ was higher than the pretest value $(\mathrm{m}=41.15$; S.D $=3.945)$. The normality test shows that the pretest data is normally distributed $(0.536>0.05)$, and the posttest data is also normally distributed $(0.598>0.05)$. Statistical tests also showed an increase in the ability to think creatively in the experimental class, as indicated by the results of the $\mathrm{N}$-gain in the experimental class 0.65 . On the basis of a gain index range of $0.50<\mathrm{g}<0.70$, this increase reveals differences in students' creative thinking abilities between before and after treatment in the experimental class using the Project Based Learning model with an increase in the moderate category. Second is for the control class. The posttest results showed an average value $(\mathrm{m}=34.54$; $\mathrm{S} . \mathrm{D}=$ 3.215) which was higher than the average pretest value $(\mathrm{m}=20.34$; S.D = 3.552). The normality and homogeneity tests revealed statistically acceptable results both in the 
pretest $(0.526>\alpha=0.05)$, and post-test $(0.788>\alpha=0.05)$. Statistical tests also showed an increase in creative thinking skills in the control class in the low category ( $\mathrm{g}=$ $0.48 \leq 0.50$ ).

Table 1. Research design and Reliability Testing

\begin{tabular}{|c|c|c|c|}
\hline Group & Pre-Test & Treatment & Post-Test \\
\hline Experiment Class & 01 & $\mathrm{X}_{1}$ & 03 \\
\hline Control Class & 02 & - & 04 \\
\hline Odd Method Reliability & \multicolumn{3}{|c|}{0.936} \\
\hline Even Method Reliability & \multicolumn{3}{|c|}{0.967} \\
\hline
\end{tabular}

Note:01=Pre-testexperimentalclassgroup; 02=Pre-testcontrolclassgroup; 03=Post-testExperimentalClassGroup; $\quad 04=$ Post-testcontrolclassgroup; $\mathrm{X} 1=$ LearningProject-BasedLearningModel

This finding was justified by the opinions of respondents who stated that Project-Based Learning (PjBL) made teaching and learning activities more interesting and enjoyable, and motivated students to be more active in learning. This shows that $\mathrm{PjBL}$ can increase student motivation to further demonstrate creativity in implementing a project and completing schoolwork. In addition, students also feel motivated to produce work or products that have been learned during Project-based Learning. This is obtained from students' responses that the $\mathrm{PjBL}$ model activities encourage them to produce valuable products. In addition, to improve student understanding, student worksheets can also be given to students to help them to easily design projects and understand learning. Student responses reveal that student worksheets help them in designing a project. In addition, the response also emphasized the need to create worksheets that were adapted to the PjBL model to make them easier to understand.

This finding underscores the importance of encouragement for students to learn to foster creative attitudes, and is not merely limited to textual learning. Learning not only emphasizes subject matter, but must be pursued dynamically where students are actively given the opportunity to explore problems and challenges in the real world to gain deeper and contextual knowledge. The findings confirm that this kind of strategy which refers to the project-based learning model, empirically influences to improve students' ability to solve the project creatively. Theoretically, this finding confirms the argument of Helle et al. (2006) about the need for teachers to evaluate the results of student performance products during the project-based learning process. This evaluation can encourage students to display the results of the project being worked on (Helle et al., 2006). The results show that project-based learning has the potential to provide interesting and relevant learning experiences for students. This is because the focus of project-based learning lies in the principles and concepts of scientific disciplines, which involve students in investigating problem solving and other meaningful tasks, as well as giving students the opportunity to work independently in learning and making products.

Table 2. Creative thinking ability in Experiment-Control Classes

\begin{tabular}{|c|c|c|c|c|}
\hline \multirow{2}{*}{ Statistical Testing } & \multicolumn{2}{|c|}{ ExperimentalClass } & \multicolumn{2}{c|}{ ControlClass } \\
\cline { 2 - 5 } & Pretest & Posttest & Pretest & Posttest \\
\hline Descriptive Statistics & & & & \\
\hline $\mathrm{N}$ & 40 & 40 & 39 & 39 \\
\hline Min. & 18 & 36 & 12 & 29 \\
\hline Max & 39 & 57 & 28 & 45 \\
\hline Mean & 22.32 & 41.15 & 20.34 & 34.54 \\
\hline Std. Dev & 3.856 & 3.945 & 3.552 & 3.215 \\
\hline Normality (Sig*) & 0.536 & 0.598 & 0.975 & 0.484 \\
\hline Homogeneity (Sig**) & 0.512 & 0.512 & 0.526 & 0.788 \\
\hline Increased ability: & & & & \\
\hline Average Score & 21.12 & 39.16 & 19.92 & 33.34 \\
\hline Enhancement & \multicolumn{2}{|c|}{17.98} & \multicolumn{2}{c|}{13.42} \\
\hline N-Gain & \multicolumn{2}{|c|}{0.65} & \multicolumn{2}{|c|}{0.48} \\
\hline
\end{tabular}

N-Gain Index: g $>0.70$ (high); $0.50<\mathrm{g}<0.70$ (moderate); $\mathrm{g} \leq 0.50$ (low)

Table 3. Post-test results in Experiment-Control Classes

\begin{tabular}{|c|c|c|}
\hline \multirow{2}{*}{ Statistical Testing } & \multicolumn{2}{|c|}{ Posttest } \\
\hline & Experiment & Control \\
\hline \multicolumn{3}{|l|}{ Descriptive Statistics } \\
\hline $\mathrm{N}$ & 40 & 39 \\
\hline Min & 39 & 27 \\
\hline $\operatorname{Max}$ & 52 & 44 \\
\hline Mean & 40.15 & 34.55 \\
\hline Std.Dev & 3.316 & 3.215 \\
\hline Normality (Sig *) & 0.581 & 0.467 \\
\hline Homogeneity (Sig*) & \multicolumn{2}{|c|}{0.388} \\
\hline \multicolumn{3}{|l|}{ Increased ability: } \\
\hline Enhancement & \multicolumn{2}{|c|}{17.97} \\
\hline N-Gain & \multicolumn{2}{|c|}{0.64} \\
\hline
\end{tabular}

N-Gain Index: $\mathrm{g}>0.70$ (high); $0.50<\mathrm{g}<0.70$ (moderate); $\mathrm{g} \leq 0.50$ (low)

For the ability to think creatively, the test showed a difference in creative thinking skills between the experimental class students $(m=40.15)$ and the control class $(\mathrm{m}=34.55)$. The results also showed that there was an ability to think creatively in the experimental class in the moderate category $(\mathrm{g}=0.50<0.64<0.70)$ which was higher than the increase in the control class in the low category 
$(\mathrm{g}=0.50<0.47<0.70) \quad($ Table 3$)$. This shows that the Project Based Learning model is able to improve the ability to think creatively. This finding is supported by students' responses which state that they will provide various interpretations of a picture, story or problem, and are willing to apply a concept or principle in different ways. In addition, the response also shows that students giving consideration or discussing something always have a different position with the majority of groups. This shows that providing opportunities for students to give different opinions will improve students' creative thinking skills due to the many alternative thoughts and ideas available. This is also supported by the response that if they are given a problem, they will think of different kinds of ways to solve it. In the context of learning, freedom of speech in class can make them more inclined to answer questions or assignments given by the teacher in a new, easier way.

Theoretically, these findings empirically confirm a variety of previous literary arguments. Vulpe and Dinaofiiun (2011) state that teachers need to give students the opportunity to create projects where students can express or demonstrate creative thinking skills. This includes giving the opportunity to make projects in the economic field to overcome the problems that exist in their daily lives. In addition, the need to provide opportunities for flexible and creative thinking is also supported by encouragement from educational stakeholders that learning should not only bring students to the level of understanding, but encourage students to apply the knowledge gained in the cases they face (Ammermueller, 2007). This is so students can not only work as exemplified by their teacher. Here, the context of project-based learning, which is supported by providing opportunities for students to express their ideas and thoughts, is more likely to increase student understanding and offer more solutions for students to solve daily problems and school assignments. This prevents the emergence of difficulties faced by students when they face different problems in class presentations (Lubis \& Manurung, 2010).

Table 4 shows the results of the t-test scores from the post-test in the control and experimental classes. Testing with Levene's Test found a significance value of 0.000 $<0.05$. This means that there are differences in students' creative thinking skills between the experimental class and the control class.

Table 4. Independent Samples Testing in Experiment-Control Classes

\begin{tabular}{|c|c|c|c|c|c|c|}
\hline \multirow{2}{*}{ Model } & \multirow{2}{*}{ Variances } & \multicolumn{2}{|c|}{$\begin{array}{c}\text { Levene's Test for Equality } \\
\text { of Variances }\end{array}$} & \multicolumn{3}{c|}{ t-test for equality of means } \\
\cline { 2 - 7 } & & F & Sig. & t & DF & Sig. (2-tailed) \\
\hline $\begin{array}{c}\text { Creative Thinking } \\
\text { (Experiments-Controls) }\end{array}$ & Equal variances assumed & 0.955 & 0.257 & 6.883 & 77 & 0.000 \\
\cline { 2 - 8 } & Equal variances not assumed & - & - & 6.876 & 73.643 & 0.000 \\
\hline
\end{tabular}


These findings confirm students' responses to original thinking. In the experimental class, students responded well to several questionnaire items. When it comes to thinking about problems or things that nobody else has thought of, students respond that they like to put forward examples of actual events about the material being studied, and like to propose examples of the material being studied during discussions with peers. In addition, in terms of questioning old ways and trying to think of new ways, they will tend to work on problems in different ways to make it shorter and easier, and propose new ideas for solving problems more easily.

These findings highlight that creative thinking through project-based learning is one of the efforts to improve students' analytical skills. Project-based learning needs to use attractive learning models to help students understand material concepts and help students connect concepts they already have to the real world. This is consistent with the findings of previous studies which suggest that the PjBL model has great potential to provide a more interesting and meaningful learning experience for students. In addition, the PjBL is also implemented so that students become more active in learning. Nunn et al. (2016) shows that learning projects can enhance students' creative and critical abilities. Anazifa and Djukri (2017) demonstrated that there are differences in the influence of project-based learning and problem-based learning on student creativity. The findings of this study which state that there is an increase in creative thinking in the experimental class that is higher than in the control class are in line with the findings of Uziak (2016) which states that project-based learning has been widely regarded as an effective and innovative method for education, including technical education. PjBL allows students to practice professional techniques openly. These results also highlight project-based learning as the best effort to meet industry needs.

\section{Conclusions}

The study highlight that there was an higher increase in inventive thinking skills in the experimental class students group that used the project-based learning model than the creative thinking ability in the control class students who followed the expository learning model at the post-test. The difference can be seen in the final measurement (post-test), the gain value between the empirical class and the control class, as evidenced by the hypothesis test. The experimental class using the project-based learning model has the maximum level of creative thinking ability on economic subjects. These findings demonstrated that project-based learning has the potential to provide interesting and relevant learning experiences for students. The focus of learning lies in the principles and concepts of a scientific discipline, involving students in investigating problem-solving and other meaningful tasks, giving students the opportunity to work autonomously in constructing knowledge and for making products.

\section{REFERENCES}

[1] Aljughaiman, A., \& Mowrer - Reynolds, E. (2005). Teachers' conceptions of creativity and creative students. The Journal of Creative Behavior, 39(1), 17-34.

[2] Anazifa, R. D., \& Djukri, D. (2017). Project-Based Learning and Problem-Based Learning: Are They Effective to Improve Student's Thinking Skills? Jurnal Pendidikan IPA Indonesia, 6(2), 346-355.

[3] Bell, S. (2010). Project-based learning for the 21st century: Skills for the future. The Clearing House, 83(2), 39-43.

[4] Bereiter, C., \& Scardamalia, M. (2003). Learning to work creatively with knowledge. Powerful learning environments: Unravelling basic components and dimensions, 55-68.

[5] Chu, S. K. W., Tse, S. K., \& Chow, K. (2011). Using collaborative teaching and inquiry project-based learning to help primary school students develop information literacy and information skills. Library \& Information Science Research, 33(2), 132-143.

[6] Chu, S. K., Chow, K. \& Tse, S. (2011). Developing Hong Kong primary school students information literacy and IT skills through collaborative teaching and inquiry Project Based Learnig. Library \& Information Science Research. Hongkong: University of Hongkong press.

[7] De Souza Fleith, D. (2000). Teacher and student perceptions of creativity in the classroom environment. Roeper Review, $22(3), 148-153$.

[8] Fägerlind, I., \& Saha, L. J. (2016). Education and national development: A comparative perspective. Elsevier.

[9] Grigorenko, E. L., \& Sternberg, R. J. (1997). Styles of thinking, abilities, and academic performance. Exceptional children, 63(3), 295-312.

[10] Gunawan, G., Sahidu, H., Harjono, A., \& Suranti, N. M. Y. (2017). The effect of project based learning with virtual media assistance on student's creativity in physics. Cakrawala Pendidikan, (2).

[11] Helle, L., Tynjälä, P., \& Olkinuora, E. (2006). Project-based learning in post-secondary education-theory, practice and rubber sling shots. Higher education, 51(2), 287-314.

[12] Horan, C., Lavaroni, C., \& Beldon, P. (1996). Observation of the tinker tech program students for critical thinking and social participation behaviors. Novato, CA: Buck Institute for Education.

[13] Hwang, R. H., Wu, J. J., Hsiung, P. A., \& Lai, C. F. (2016). Design and implementation of a learning platform for a computer science capstone course based on project-based learning and creative thinking. In 44th Annual Conference of the European Society for Engineering Education-Engineering Education on Top of the World: Industry-University Cooperation, SEFI 2016. European 
Society for Engineering Education (SEFI).

[14] Kozma, R. B. (2005). National policies that connect ICT-based education reform to economic and social development. Human Technology: An interdisciplinary journal on humans in ICT environments.

[15] Kusumawardhani, P. N. (2017). Does teacher certification program lead to better quality teachers? Evidence from Indonesia. Education economics, 25(6), 590-618.

[16] Le Cornu, R. (2015). Key components of effective professional experience in initial teacher education in Australia. Australian Institute for Teaching and School Leadership, Melbourne.

[17] Lubis, A. R., \& Manurung, B. (2010). Pengaruh Model dan Media Pembelajaran Terhadap Hasil Belajardan Retensi Peserta didik pada Pelajaran Biologi di SMP Swasta Muhammadiyah Serbelawah. Jurnal Dikbio, 1(3), 186-206.

[18] Mihardi, S., Harahap, M. B., \& Sani, R. A. (2013). The effect of project based learning model with kwl worksheet on student creative thinking process in physics problems. Journal of Education and Practice, 4(25), 188-200.

[19] Mills, J. E., \& Treagust, D. F. (2003). Engineering education-Is problem-based or project-based learning the answer. Australasian journal of engineering education, 3(2), $2-16$.

[20] Nunn, R., Brandt, C., \& Deveci, T. (2016). Project-based learning as a holistic learning framework: Integrating 10 principles of critical reasoning and argumentation. Asian Journal of English for Specific Purposes, 12(2), 9-53.

[21] Prasetyo, B., \& Jannah, L.M. (2005). Quantitative Research Methods: Theory and Application (in Indonesian). Jakarta: Penerbit PT.Raja Grafindo. Persada

[22] Samir, K. C., \& Lutz, W. (2017). The human core of the shared socioeconomic pathways: Population scenarios by age, sex and level of education for all countries to 2100 . Global Environmental Change, 42, 181-192.

[23] Sari, D. K., Permanasari, A., \& Supriyanti, F. M. T. (2017). Profile of Students' Creative Thinking Skills on Quantitative Project-Based Protein Testing using Local Materials. Jurnal Pendidikan IPA Indonesia, 6(1).

[24] Savery, J. R. (2015). Overview of problem-based learning: Definitions and distinctions. Essential readings in problem-based learning: Exploring and extending the legacy of Howard S. Barrows, 9, 5-15.

[25] Snyder, L. G., \& Snyder, M. J. (2008). Teaching critical thinking and problem solving skills. The Journal of Research in Business Education, 50(2), 90.

[26] Sugilar, H. (2013). Meningkatkan Kemampuan Berpikir Kreatif dan Disposisi Matematik siswa Madrasah Tsanawiyah Melalui Pembelajaran Generatif. Jurnal Ilmsiswah.

[27] Taniredja. T, \& Mustafidah, M. (2011). Quantitative Research: An Introduction (in Indonesian). Bandung: Alfabeta.

[28] Tretten, R., \& Zachariou, P. (1995). Learning about PjBL Self-Assessment Preliminary Report of Results. San Rafael, CA:The Autodesk Foundation.
[29] Trianto, T. (2015). Cooperative Learning Model on Developmental of Biology. American Journal of Educational Research, 3(10), 1298-1304.

[30] Uziak, J. (2016). A project-based learning approach in an engineering curriculum. Global Journal of Engineering Education, 18(2), 119-123.

[31] Vulpe, A., \& Dafinoiu, I. (2011). Positive emotions' influence on attitude toward change, creative thinking and their relationship with irrational thinking in Romanian adolescents. Procedia-Social and Behavioral Sciences, 30, 1935-1941.

[32] Yanuarti, E., \& Treagust, D. F. (2016, April). Reflective teaching practice (teachers' perspectives in an Indonesia context). In 1st UPI International Conference on Sociology Education. Atlantis Press. 